УДК 631.153.3:632.7

(C) 2013

\author{
Антонець С. С., засновник, \\ Антонець А. С., співзасновник, \\ Лук'яненко Т. В., генеральний директор \\ ПП «Агроекологія» Шишацького району Полтавської області \\ Писаренко В. М., Писаренко П. В., доктори сільськогосподарських наук, \\ Писаренко В. В., доктор економічних наук \\ Полтавська державна аграрна академія
}

\title{
СОЦІАЛЬНО-ЕТИЧНІ ЗАСАДИ ОРГАНІЧНОГО ЗЕМЛЕРОБСТВА
}

\section{Рецензент - доктор сільськогосподарських наук, професор Н. А. Макаренко}

\begin{abstract}
Викладено результати досліджень доиільності заміни агрохімічної кониепиії землеробства на агробіологічну. Цьому у найбільшій мірі підпорядковане органічне землеробство, виробничою філософією якого є турбота про землю, отримання екологічно безпечних продуктів харчування, які $\epsilon$ одним із основних чинників здоров'я людини.
\end{abstract}

Ключові слова: екологія, органічне землеробство, агробіологічна кониепиія, продукти здорового харчування, екологічні пріоритети.

Постановка проблеми. Людина $\epsilon$ частиною природи й одночасно бере активну участь у іiі житті як виробник і як споживач. Тому людство має бути безпосередньо зацікавленим у збереженні та примноженні родючості земель, а методи ведення сільського господарства повинні перебувати не лише в центрі уваги вузького кола професійного інтересу, а й стати пріоритетом загальнолюдського, культурного життя народу.

У наш час, коли повітря, вода і земля забруднені продуктами життєдіяльності людини й екологічна обстановка, попри всі зусилля, продовжує погіршуватися, люди все більше й більше починають замислюватися про вплив екології на власне здоров'я. I це не безпідставна тривога: нині понад $90 \%$ людей хворіють у працездатному віці, а досягнувши пенсійного рубежу, мають уже цілий «букет» недуг. Смертність громадян активного віку (від 20 до 50 років), тобто в розквіті сил, збільшилася в 2,2 разу і в 3-4 рази перевищує цей показник у країнах Західної Європи.

Аналіз останніх досліджень і публікацій, у яких започатковано розв'язання проблеми, свідчить, що негативна динаміка розвитку подій може призвести до того, що сьогоднішні онуки проживуть на 8-11 років менше, ніж їхні бабусі й дідусі. Нині 85 \% школярів мають істотні відхилення у показниках здоров'я, а від 60 до $80 \%$ юнаків - ще й різні обмеження в придатності до армійської служби. Середня тривалість життя українців за два останніх десятиліття скоротилася на три роки. Усе це значною мірою зумовлено екологічною ситуацією, негативний вплив людини на яку очевидний. Чекати кращих часів, сприятливих для вирішення цієї проблеми, вже ніколи, адже за таких обставин «світле завтра» може й не настати [3].

Нині вміст речовин, шкідливих для здоров'я людини, у повітрі, воді, грунті та продуктах харчування нерідко досягає критичних показників. I хоча агрохімікати, у загальному обсязі шкідливих для людини речовин, займають непровідне місце, та вони безпосередньо впливають на якість продуктів харчування, а тому є особливо небезпечними. Українці змушені вживати в їжу продукти, які можуть завдати непоправної шкоди їхньому життю і здоров'ю.

Мета дослідження: обгрунтувати необхідність широкого впровадження органічного землеробства як важливого чинника отримання екологічно безпечних продуктів харчування.

Завдання: обгрунтувати взаємозв'язок здоров'я людини 3 продуктами харчування.

Результати досліджень. Єдиним виходом із кризової ситуації, що склалася, має стати зміна агрохімічної концепції землеробства на агробіологічну - таку, що узгоджується із законами Природи. Закони ці прості: рослини засвоюють i концентрують у собі енергію Сонця, частково передають іiі тваринам. Відмерлі рослини й тварини та їх виділення потрапляють у землю й дістаються на харч грунтовим мікроорганізмам. Грунтові мікроорганізми переробляють і знову передають накопичені у грунті органічні та мінеральні речовини рослинам. Елементи, яких їм бракує, вони добувають із повітря та грунтових мінералів, використовуючи для цього все ту ж накопичену рослинами сонячну енергію. Цей кругообіг триває вже мільйони років - він є запорукою продовження життя на Землі. І якщо ми 
не хочемо перервати цей процес життя, то повинні дотримуватися законів Природи й мудро їх використовувати.

Земля - це єдиний живий організм, який постійно самовдосконалюється. В шарі грунту глибиною $30 \mathrm{~cm}$ на $1 \mathrm{~m}^{2}$ степу мешкає близько 2 кг бактерій, актиноміцетів і грибків; близько 100 г інфузорій та інших найпростіших; до 50 г нематод, кліщів, ногохвосток; до 100 г молюсків і до 500 г хребетних. Уся ця «юрба» живе завдяки тому, що споживає за сезон близько 10 кг органіки. Ця унікальна у Всесвіті сукупність - рослини, тварини, гриби і мікроби, які процвітають у створеному для себе домі, - оце і $є$ животворний грунт, кращі властивості якого можуть бути збережені тільки в системі природних технологій.

Тому виробничою філософією аграрного сектора повинна стати турбота про землю, створення оптимальних умов життєдіяльності грунтової біоти, що забезпечить отримання екологічно безпечних продуктів харчування $[1,4,5]$. Найголовнішою, першочерговою метою на цьому шляху стане піклування про людину, їі здоров’я, а вже потім - отримання прибутку.

На ринку продуктів харчування сьогодні безліч пропозицій стосовно здорового харчування. Та чи існує один-єдиний спосіб вирішення проблеми здорового харчування? Так, він існує. I, як все геніальне, - він простий: для цього необхідно виростити сировину в екологічно чистому середовищі, а також переробити й упакувати їі екологічно чистим способом.

Чому саме це рішення є безальтернативним? Відповідь і на це запитання проста: продукти, створені природою без використання неприродних субстанцій, найбільш повно й збалансовано містять у собі всі необхідні для життєдіяльності людського організму речовини. У цьому разі можна вжити фразу: «Зроблено природою», i вона буде найбільш повно характеризувати якість отриманого продукту.

Органічне сільське господарство - це наразі єдина виробнича система, що підтримує й покращує стан грунтів, екосистем, а тому - й людей. Вона базується на природних процесах, біорізноманітті, виключає методи господарювання 3 несприятливими наслідками, поєднує традиції, інновації та наукові досягнення 3 метою отримання максимальної користі від природних ресурсів, поширюючи гармонійні стосунки та забезпечуючи високу якість життя всім, хто залучений до цієї системи.

Екологічно безпечні харчові продукти виробляють на основі сільськогосподарської сирови- ни, вирощеної за технологіями органічного землеробства, якими не використовуються синтетичні агрохімікати, генетично модифіковані організми, проводиться мілкий обробіток грунту. Такі продукти не шкідливі для людського організму: овочі не містять нітратів і залишків пестицидів, ковбаса й шинка - канцерогенів, йогурти та сирки - штучних підсилювачів смаку, фарбників і консервантів. Вони багаті на вітаміни, мінерали та біологічно активні речовини. Тому такі продукти - джерело здоров'я, енергії та бадьорості. У зв'язку з цим органічне виробництво, яке $є$ основою створення такої продукції, набуває значного поширення.

Технології органічного виробництва спрямовані на поліпшення екологічного стану довкілля, підвищення конкурентоспроможності вітчизняної сільськогосподарської продукції. Водночас розвиток органічного виробництва має важливе соціально-економічне значення, поскільки створює сприятливі умови для розбудови сільських територій, суттєво сприяє підвищенню рівня зайнятості та добробуту населення, забезпечує сталий розвиток сільських територій, зміцнює економіку держави, а отже, є державною програмою.

Настав час нового агрономічного мислення 3 екологічними пріоритетами. Епоха існування людства, яка не відкидає інтенсифікації галузі, але передбачає максимальну узгодженість іï 3 законами Природи. Отримана без застосування агрохімікатів продукція рослинництва й тваринництва - не тільки здоров'я наше і наших дітей, а й здоров'я довкілля й грунтів. Це та продукція, 3 якою можемо вийти на зовнішні ринки й 3 оптимізмом дивитись у майбутнє.

Одним із можливих шляхів впровадження раціонального природокористування $\epsilon$ локальне вирішення глобальних проблем. Це означає, що кожен аграрій здатен вирішувати глобальну екологічну проблему збереження планети локально у себе в господарстві.

Майже сорокарічний успішний досвід ПП «Агроекологія» довів, що впровадження органічного землеробства, на тлі підвищення родючості грунту, дає можливість досягати урожаїв на рівні інтенсивного землеробства, але при цьому вирощувати продукцію екологічно безпечну для здоров'я людей. Здорова земля - здорова людина. Семен Свиридонович Антонець переконаний, що органічне землеробство здатне вже у найближчі роки забезпечити все населення України високоякісними продуктами харчування. Для цього потрібно лише краще усвідомити закони 
землеробства, відкрити для себе нові шляхи отримання високих урожаїв якісної продукції, глибше пізнати взаємозв'язок землі, рослин, тварин, людини і Космосу.

За сучасних умов соціально-етична концепція органічного землеробства повинна стати фундаментом діяльності всіх аграрних підприємств, оскільки вона є важливою передумовою удосконалення виробництва.

Світовий ринок потребує активного залучення аграрного потенціалу України в світову економіку. 3 огляду на грунтово-кліматичні умови, вигідне географічне розташування в центрі Свропи та давні аграрні традиції, Україна має значні можливості широкого виробництва органічної сільськогосподарської продукції та її експорту.

Обсяги виробництва української екологічно безпечної продукції щорічно збільшуються на 15-20\%. Ринок органічних продуктів (незважаючи на кордони) залишається одним із найцікавіших ринків харчової промисловості, що розвивається сьогодні й зростатиме в майбутньому.

Висновки: 1. Можна з упевненістю та оптимізмом прогнозувати, що в найближчі 3-4 роки Україна матиме всі шанси ввійти до клубу першої «десятки» світових виробників органічної продукції. Цьому, зокрема, сприятиме виконання Державної цільової програми розвитку українського села на період до 2015 року, якою заплановано збільшити площі сільськогосподарських угідь, сертифікованих відповідно до органічних стандартів, до 5 \% у 2015 р. та на 7 \% - у 2020 р.,

\section{БІБЛІОГРАФІЯ}

1. Бентежний талант хлібороба: штрихи до портрета агроеколога Семена Антонця / Укладачі Самородов В. М., Поспєлов С. В; наук. ред. В. М. Самородов. - Полтава : Дивоствіт, 2010. $236 \mathrm{c}$.

2. Довбан К. И. Зеленое удобрение в современном земледелии. - Мн. : Белорусская наука, 2009. - 404 с.

3. Електронний ресурс. Режим доступу: проти $0,7 \%$ у 2010 році.

2. Здорова нація - одна з головних запорук подальшого прогресу суспільства. Мати здорову націю в Україні вдасться лише за умови якісного, екологічно безпечного і здорового харчування, сировину для якого можуть забезпечити виключно технології органічного землеробства. Тому органічне землеробство, що стає одним із найважливіших чинників забезпечення здорового способу життя, значною мірою впливатиме на інтелект i творчий потенціал кожної людини i всієї нації.

3. Широке впровадження органічного виробництва має стати одним із пріоритетних напрямів державної аграрної політики в найближчому майбутньому, і це під силу нинішньому поколінню українців. Є досвід, $є$ наукові розробки, потрібно ще бажання й рішучі дії лідерів нації, активна і цілеспрямована участь держави не силою та вказівками, а 3 допомогою економічних державних стимулів і дотацій, що мають базуватися на законодавчій основі. Аграріям, які стали на шлях екологізації своїх господарств, необхідна системна підтримка, що діятиме постійно, а не у вигляді разових бюджетних подачок.

4. Широке застосування органічного землеробства, виробництво на його основі екологічно безпечної продукції, збереження й примноження родючості українських чорноземів повинно бути поставлене в ранг державної програми - i тоді виграють усі: держава, нація, нинішнє і майбутні покоління українців.

http://www.organic.ua

4. Органічне землеробство: $з$ досвіду ПП «Агроекологія» Шишацького району Полтавської області / Антонець С. С., Антонець А. С., Писаренко В. М. [та ін.] - Полтава : Камелот, 2010. - 198 с.

5. Писаренко В. В., Писаренко П. В., Писаренко В. М. [ma iн.]. Еколого-економічна ефективність використання сидератів. - Вісник ПДАА, 2012. № 3. - С. 122-126. 